\title{
The Critically Endangered Flora and Fauna of District Battagram Pakistan
}

\author{
Faizul Haq ${ }^{1,2}$ \\ ${ }^{1}$ Department of Botany, Hazara University, Mansehra Pakistan \\ ${ }^{2}$ Department of Botany, Government Degree College, Battagram Pakistan
}

\begin{abstract}
Present study was conducted to evaluate the diversity, population status and problems associated with the conservation of flora and fauna of District Battagram of western Himalayan Pakistan. A total of 22 species were reported as Critically Endangered locally including 12 plant and 10 animal species. The data were collected through field observation and from the natives. Major threats to the flora and fauna of the study area are loss of habitat, unplanned collection, deforestation, over grazing, erosion, attack of pathogens, effect of introduced taxa and hunting, shooting and trapping of wild animals.
\end{abstract}

Keywords Conservation, Flora, Fauna, Major Threats, Battagram, Pakistan

\section{Introduction}

District Battagram is located between $34^{\circ} 33^{\prime}$ and $34^{\circ} 47^{\prime}$ $\mathrm{N}$ and $72^{\circ} 54^{\prime}$ and $73^{\circ} 15^{\prime} \mathrm{E}$ in the western Himalayan province of Khyber Pakhtunkhwa Pakistan, with a total area of $1,301 \mathrm{~km}^{2}[1,2]$. District Battagram is bounded by the Kohistan valley in the north, Siran valley in the east, the Konsh and Agror valleys in the south and the Black mountain and river Indus in the west $[3,4]$.

Swatis, Khankhel, Akhunkhel, Syeds and Gujars inhabit District Battagram with a small population of Kashmiries and Kohistanies. The entire population of the tract is Muslim with the exception of only a few Sikh families in Shamlai and Battagram[2].

District Battagram is mountainous region ranging in altitude from $525 \mathrm{~m}$ at Thakot to $4690 \mathrm{~m}$ above mean sea level at Sukaisar. The area is generally rough and mountainous having variable slopes from gentle to precipitous. The climate varies from sub tropical at the base of the hills to "alpine" conditions on the higher reaches. District Battagram can be categorised into agricultural land, wasteland, forest and alpine meadows[5,6]. Majority of the people are dependent on agriculture as a first source of livelihood, followed by pasture animal husbandry. They grow rice, maize, wheat, red beans and vegetables. All small streams coming from the sub valleys join two main streams Nandiar Khuwar and Allai Khuwar in District Battagram to jo in River Indus [3,4].

District Battagram is underlined by metamorphic and

Corresponding author:

faizulhaq80@yahoo.com (Faizul Haq)

Published online at http://journal.sapub.org/als

Copyright (C) 2012 Scientific \& Academic Publishing. All Rights Reserved plutonic igneous rocks which are in turn intruded by pegmatite, aplites and quartz veins. Quaternary alluvium and glacial deposits are common[3]. Low grade metamorphic rocks like Graphite schist, Re-crystalline lime stone, Amphibole schist, Quartz-mica Schist and green schist are exposed in the area. Granite, Ultra mafic and massive amphibolites cover large area[2]. The surface soil is formed by the weathering of the parent rocks. The top soil is constantly being washed away by run off fro $m$ higher slopes. The soil under fir and spruce is deep and quite rich in humus, whereas it is shallow and poor under pines and scrub zones including Waste Land[4].

The vegetation zones of District Battagram fall under mo ist temperate category of the internationally known Western Himalayan Moist temperate ecology. District Battagram forests can further be classified into six categories on the bas is of available indicator plant species. These includes tropical sub humid forests, sub tropical Chir-pine forests, moist temperate blue pine forests, mixed coniferous forest, pure fir and spruce forests and alpine pastures.

Biodiversity is the degree of variation in life forms within a given species, ecosystem, biome, or an entire planet. Biodiversity is a measure of the health of a given ecosystem and in terrestrial habitats the tropical regions are rich, whereas polar regions support fewer species[2]. Generally terrestrial biodiversity is up to 25 times greater than ocean biodiversity[11].

About $1 \%$ of the existed species of the Earth are extant due to environmental changes that caused mass extinctions[7]. There are five major mass extinctions that have led to large and sudden drops in biodiversity on Earth. The Phanerozoic eon marked a rapid growth in biodiversity via the Cambrian explosion. The next 400 million years 
included repeated, massive biodiversity losses classified as mass extinction events [8-10]. The Holocene extinction due to habitat destruction by humans caused loss of genetic diversity. Biodiversity impacts human health in a number of ways, both positively and negatively.

Pakistan is under tremendous ecological stress due to its population explosion, urbanization, deforestation and over exploitation of natural resources[12]. The natural forests of Pakistan are rapidly declining at a rate of $4-6 \%$ per year, resulting in a decline in population size of both flora and fauna[13].

The ethno-botanical uses and conservation status of vascular plants of Nandiar valley part of District Battagram has been recently studied[1,2,6]. However the detailed information regarding the diversity and conservation status of the flora and fauna of District Battagram is not available, hence present investigation is being proposed with following objectives.

- To explore the species diversity of flora and fauna of District Battagram

- To study the conservation status of important species.

- To study the major threats to the flora and fauna of the selected area.

- To recommend ways for sustainable utilization of the local recourses.

\section{Materials and Methods}

A survey was conducted to study the diversity, conservation status and major threats to the important species of flora and fauna of District Battagram. The information regarding their conservation status was collected through direct field observation and through questionnaire. Each species was individually evaluated in the field for its use patterns, historical range of distribution, present frequency and compared with the existing extent and its normal ecological niche. The number of species scored with reference to its ecological amplitude and calculated historical distribution were compared with IUCN criteria (IUCN, 2001), for elaborating the conservation status of the species concerned.The instruments used during the survey include, GPS, Binoculars, Clinometers, Digital camera and Audio recorder. The additional secondary information was taken from published and unpublished literature.

In present study the conservation status of 22 species were studied in District Battagram. These include 12 plants and 10 animal's species. These species were evaluated against IUCN criteria Version 3.1, and were placed as Critically Endangered species locally. These investigations were based on population reduction criteria $\mathrm{A}$, geographic range criteria $\mathrm{B}$, s mall population size criteria $\mathrm{C}$ and very small or restricted population criteria D.

\section{Results}

During the present survey variety of flora and fauna were studied. The study areas included the different sub valleys of District Battagram. On the basis of available indicator of plant species the forests of District Battagram falls under Moist Temperate category of the internationally known Western Himalayan Moist Temperate ecology and can be divided into following six sub-categories.

( i ) Tropical Sub Humid Forest found up to an elevation of $900 \mathrm{~m}$, consisting of small trees and thorny shrubs.

( ii ) Sub Tropical Chir-Pine Forests occurs at the altitudinal zone ranging between 900 to $1500 \mathrm{~m}$.

(iii) The Moist Temperate Blue Pine Forest occurs at the altitudinal zone ranging between 1500 to $2300 \mathrm{~m}$.

(iv) Mixed Coniferous Forests occur between elevations of 2300 to $2800 \mathrm{~m}$.

(v) Pure Fir and Spruce Forests found on the elevation ranging from 2800 to $3050 \mathrm{~m}$.

(vi) Alpine Pastures stretches above the tree limit with excellent grasses and forbs available during summer season.

The Critically endangered flora is given in table 1 while the critically endangered fauna are presented in table 2 .

\subsection{The Critically Endangered Flora of District Battagram}

The Critically Endangered flora of District Battagram consists of 12 plants species. Their conservation status was studied through direct field observation and the information given by local people. The decline in the population size of these species were due to its area of occupancy, extent of occurrence, loss of habitat, actual or potential level of exploitation, effects of introduced taxa and attack of pathogens.

\subsubsection{Acer Caesium Wall}

Acer caesium is found between an elevation of 2200 to $3200 \mathrm{~m}$ above mean sea level on open grassy places in District Battagram. Acer caesium is Critically Endangered locally under criteria $\mathrm{A}$, as its total population size has been reduced by $86 \%$ in last 10 years[14]. It follows the criteria A2 (a, c, d) of Critically Endangered species.

\subsubsection{Betula Utilis D. Don}

Betula utilis is found in higher altitudinal zones between 2800 to $4000 \mathrm{~m}$ in Allai and Hallian sub valleys. Betula utilis is locally collected for fuel wood, leaf fodder and bark paper for a mulet due to its medicinal properties. The plant is Critically Endangered locally as its population size has been reduced by $98 \%[14]$ within past 10 years, falling under criteria A2 (a, b, c, d) of critically endangered.

\subsubsection{Cedrus Deodara Roxb. ex Lamb}

Forty-one mature individuals of Cedrus deodara were found in altitudinal zones of 1800 to $3000 \mathrm{~m}$. Due to its collection for fuel wood, timber and medicinal uses, the plant is Critically Endangered locally as its population size has been reduced by $98 \%$ falling under criteria A 1 ( $a, b, c$, 
d), and D of Critically Endangered species.

\subsubsection{Opuntia Dilleni Haw}

Opuntia dilleni was found up to an elevation of $1500 \mathrm{~m}$, covering an area of $5 \mathrm{~km}^{2}$ and its population size has been reduced by $85 \%$. Opuntia dilleni is Critically Endangered under population reduction criteria $\mathrm{A} 2(\mathrm{a}, \mathrm{b}, \mathrm{c}, \mathrm{d}, \mathrm{e})$ and with geographical range criteria B2 $(b, c)$ in the form of area of occupancy less than $10 \mathrm{~km}^{2}$. The reduction in population size is due to loss of habitat, uprooted by farmers, effect of introduced taxa and attack of pathogens.

\subsubsection{Paeonia Emodi Wall. ex Hook. f}

Paeonia emodi was found in altitudinal zones between 2200 to $3200 \mathrm{~m}$. It is collected for medicinal uses. Paeonia emodi is Critically Endangered locally as its total population size reduced by $81 \%$, falling under criteria $\mathrm{A} 2$ (a, b, c, d) of Critically Endangered species.

\subsubsection{Pistacea Integerrima (J. L. Stewart) Rech.f}

Pistacea integerrima were found up to an elevation of $1400 \mathrm{~m}$ in different parts of District Battagram. Pistacea integerrima is locally collected for fuel wood and for medicinal purposes. Its population size has been reduced by 93\%[14] and therefore falls under criteria A1 (a, b, c, d, e) of Critically Endangered species.

\subsubsection{Populus Alba Linn}

Populus alba was found up to an elevation of 1500 to $2200 \mathrm{~m}$, restricted only to Sarmast, covering an area of 3 $\mathrm{km}^{2}$. It is collected for fuel wood, timber and medicinal uses. Populus alba is Critically Endangered locally with geographical range criteria $\mathrm{B} 2(\mathrm{a}, \mathrm{b})$ in the form of area of occupancy less then $10 \mathrm{~km}^{2}$.

\subsubsection{Quercus Glauca Thunb}

Quercus glauca is locally known as Banjay and their species are restricted only to Gada. It covers an area of 3 $\mathrm{km}^{2}$ between an elevation of 1300 to $1600 \mathrm{~m}$. Quercus glauca is Critically Endangered under criteria B2 $(a, b)$ and also falls within $\mathrm{C} 2$ (a ii) with all individuals in one sub population.

\subsubsection{Skimmia Laureola D.C}

Skimmia laureola is found at altitudinal zones of 2400 to $3400 \mathrm{~m}$. The population size is reduced due to medicinal collection and loss of habitat due to over grazing. Skimmia laureola is Critically Endangered under population size reduction criteria $\mathrm{A} 2(\mathrm{a}, \mathrm{b}, \mathrm{c}, \mathrm{d})$, as the population size reduced by $81 \%$ in past 10 years.

\subsubsection{Taxus Baccata L. Subsp. Wallichiana (Zucc.) Pilger}

Taxus wallichiana was found at altitudinal zones of 2100 to 3400 m of Hillian and Allai sub valleys. It is used for fuel wood, medicinal and in graves. Taxus wallichiana is
Critically Endangered under population size reduction criteria A2 (a, b, c, d), as the population size reduced by $87 \%$. It is very rarely distributed.

\subsubsection{Ulmus Wallichiana Planch}

Ulmus wallichiana has only 44 mature individuals in different parts of District Battagram between in altitudinal range of 1300 to $2000 \mathrm{~m}$. Most of the plants are found in graveyards and only few plants of this taxon are found along the paddy fields and other water bodies. It falls under criteria D of Critically Endangered species. The reduction in its population size is due to fuel wood collection, timber, wood used in making house tools, loss of habitat and change in environment[14].

\subsubsection{Viscum Album Linn}

Viscum album, the parasitic epiphyte of Ulmus wallichiana is also Critically Endangered species under criteria D. Among the 44 host plants Viscum album was only found on 15 plant species. Therefore, the loss of the host plants has also reduced the population size of Viscum album.

Table 1. The Critially Endangered flora of District Battagram

\begin{tabular}{|c|c|c|c|}
\hline & Botani cal Name & Criteria & Sub crite ria \\
\hline 1 & Acer caesium Wall. & $\mathrm{A}$ & $\mathrm{A} 2(\mathrm{a}, \mathrm{c}, \mathrm{d})$ \\
\hline 2 & Betula utilis & $\mathrm{A}$ & $\mathrm{A} 2(\mathrm{a}, \mathrm{b}, \mathrm{c}, \mathrm{d})$ \\
\hline 3 & Cedrus deodara & $\mathrm{A}$ and D & $\mathrm{A} 1(\mathrm{a}, \mathrm{b}, \mathrm{c}, \mathrm{d})$ \\
\hline 4 & Opuntia dilleni & A and B & $\begin{array}{c}\mathrm{A} 2(\mathrm{a}, \mathrm{b}, \mathrm{c}, \mathrm{d}, \mathrm{e}) \text { and } \\
\mathrm{B} 2(\mathrm{~b}, \mathrm{c})\end{array}$ \\
\hline 5 & Paeonia emodi & $\mathrm{A}$ & $\mathrm{A} 2(\mathrm{a}, \mathrm{b}, \mathrm{c}, \mathrm{d})$ \\
\hline 6 & Pistacea integerrim a & $\mathrm{A}$ & $\mathrm{A} 1(\mathrm{a}, \mathrm{b}, \mathrm{c}, \mathrm{d}, \mathrm{e})$ \\
\hline 7 & Populus alba & $\mathrm{B}$ & $\mathrm{B} 2(\mathrm{a}, \mathrm{b})$ \\
\hline 8 & Quercus glauca & $\mathrm{B}$ and C & $\mathrm{B} 2(\mathrm{a}, \mathrm{b})$ and $\mathrm{C} 2(\mathrm{a}$ ii $)$ \\
\hline 9 & Skimmia laureola & $\mathrm{A}$ & $\mathrm{A} 2(\mathrm{a}, \mathrm{b}, \mathrm{c}, \mathrm{d})$, \\
\hline 10 & Taxus wallichiana & $\mathrm{A}$ & $\mathrm{A} 2(\mathrm{a}, \mathrm{b}, \mathrm{c}, \mathrm{d})$, \\
\hline 11 & Ulmus wallichiana & $\mathrm{D}$ & \\
\hline 12 & Viscum album & $\mathrm{B}$ and D & \\
\hline
\end{tabular}

\subsection{The Critically Endangered Fauna of District Battagram}

The Critically Endangered fauna of District Battagram consists of 10 species. These include;

\subsubsection{Alectoris Chukar}

The estimated population of Alectoris chukar (locally known as Zarka) in District Battagram were aproximately 2600 individuals. The Alectoris chukar were found in all type of forests except scruby forests in District Battagram. The Alectoris chukar is Critically Endangered under critera $\mathrm{A} 3(\mathrm{~b}, \mathrm{c}, \mathrm{d})$.

\subsubsection{Lophophorus Impejanus (Monal Pheasant)}

Monal Pheasant is locally known as late sham. The Monal Pheasant were observed between an elevation of 2400 to $3400 \mathrm{~m}$. The estimated population of Monal Pheasant ranges from 1550 to 1600 male and 2100 to 2200 female individuals in District Battagram. Monal Pheasant is 
Critically Endangered under criteria A 3 (b, c, d) of IUCN criteria.

\subsubsection{Lophura Leucomelana (Kalij Pheasant)}

Kalij Pheasant is locally known as Ban kukar. The estimated population of this species was about 1000 to 1050 . This falls under criteria A3 (b, c, d) of IUCN criteria of Critically Endangered species.

\subsubsection{Martes Flavigula (Yellow Throated Martin)}

The population size of Yellow throated martin ranges between 130 and 150. It is Critically Endangered under criteria C2 (ai, aii) of IUCN criteria version 3.1.

\subsubsection{Panthera Pardus (Common Leopard)}

The common leopard locally known as Chita frequents Himalayan mountains upto the tree limit in mixed coniferous forests and pure Abies pindrow and Picea smithiana forests. Eight individuals of Common Leopard were seen in different parts of District Battagram from time to time. The Common Leopard falls under criteria D of Critically Endangered species.

\subsubsection{Prionailurus Bengalensis (Leopard Cat):}

A total of 34 mature individuals of Leopard Cat locally known as Chita Billi were seen in coniferous forests of District Battagram between an elevation of 2000 and 3200 meters. Leopard Cat falls under criteria D of Critically Endangered species as its total mature individuals are less then 50 .

\subsubsection{Pucrasia Macrolopha (Koklass Pheasant)}

The estimated population of Kokloss Pheasant locally known as Baigar comprised of 344 mature individuals. Kokloss Pheasant is Critically Endangered under criteria A2 (a, b, c, d) of IUCN criteria.

\subsubsection{Uncia Uncia (Snow Leopard)}

The snow leopard commonly called as Barfani Chita generally inhabits an elevation between 2000-4000 meters. Six mature individual of snow leopard were seen in District Battagram. It falls under criteria D of Critically Endangered species.

\subsubsection{Ursus Arctos (Brown bear)}

The Brown bears inhabit Abies pindrow and Picea smithiana forests. A total of two mature individuals were seen in Allai valley. Brown bear falls under category D of critically endangered.

\subsubsection{Ursus Thibetanus (Black bear)}

The Black bears locally known as Yeg frequents in mixed coniferous forests and pure Abies pindrow and Picea smithiana forests. These were 12 in number in selected area; hence fall under category D of Critically Endangered species.

Table 2. The critically endangered fauna of District Battagram

\begin{tabular}{|c|c|c|c|}
\hline & Zoological Name & Criteria & Sub crite ria \\
\hline 1 & Alectoris chukar & A & $\mathrm{A} 3(\mathrm{~b}, \mathrm{c}, \mathrm{d})$ \\
\hline 2 & Lophophorus impejanus & $\mathrm{A}$ & $\mathrm{A} 3(\mathrm{~b}, \mathrm{c}, \mathrm{d})$ \\
\hline 3 & Lophura leucomelana & $\mathrm{A}$ & $\mathrm{A} 3(\mathrm{~b}, \mathrm{c}, \mathrm{d})$ \\
\hline 4 & Martes flavigula & $\mathrm{C}$ & $\mathrm{C} 2(\mathrm{ai}, \mathrm{aii})$ \\
\hline 5 & Panthera pardus & $\mathrm{D}$ & \\
\hline 6 & $\begin{array}{c}\text { Prionailurus } \\
\text { bengalensis }\end{array}$ & $\mathrm{D}$ & \\
\hline 7 & Pucrasia macrolopha & $\mathrm{A}$ & $\mathrm{A} 2(\mathrm{a}, \mathrm{b}, \mathrm{c}, \mathrm{d})$ \\
\hline 8 & Uncia uncia & $\mathrm{D}$ & \\
\hline 9 & Ursus arctos & $\mathrm{D}$ & \\
\hline 10 & Ursus Thibetanus & $\mathrm{D}$ & \\
\hline
\end{tabular}

\subsection{Major threats to the Flora and Fauna of District Battagram}

The major threats to the flora and fauna of District Battagram includes; over population, urbanization, hunting, shooting and trapping of wild fauna, deforestation due to illicit cutting and smuggling of trees, clearance of forests for cultivation, grazing and browsing by all kinds of domestic animals damages the regenerated plants, lopping, forest fire, snow drift and avalanches at high attitudes and steep slopes, lighting, erosion and lands lide.

\section{Discussion}

There are certain direct threats to the flora and fauna according to IUCN classification[15]. Habitat destruction has a key role in extinctions[16]. Habitat size and numbers of species are systematically related. The factors that are responsible for the loss of habitats are; deforestation, overpopulation, changes in environment, global warming and pollution[17]. Co-extinctions are also a form of habitat destruction. Co-extinction occurs when the extinction or decline in one accompanies the other, such as in plants and beetles [18].

Invasive species occurs when the barriers such as rivers, seas, oceans, mountains and deserts are blurred. Without such barriers, species occupy new niches, substantially reducing diversity. Repeatedly humans have helped these species circumvent these barriers, introducing them for food and other purposes.

An introduced species may unintentionally injure a species that depends on the species it replaces. Introducing new species often leaves endemic and other local species unable to compete with the exotic species and unable to survive. The exotic species may be predators, parasites, or may simply outcompete indigenous species for nutrients, water and light.

Endemic species can be threatened with extinctions[19] through the process of genetic pollution such as uncontrolle d hybridization, introgression and genetic swamping. Genetic pollution leads to homogenization or replacement of local genomes as a result of either a numerical and/or 
fitness advantage of an introduced species[20]. Hybridization and introgression are side-effects of introduction and invasion.

Overexploitation occurs when a resource is consumed at an unsustainable rate. This occurs on land in the form of overhunting, excessive logging, poor soil conservation on agriculture land and illegal wildlife trade[21].

Hybridization have collapsed the gene pools of various wild and indigenous breeds, resulting in genetic erosion and genetic pollution have caused loss of genetic diversity and biodiversity as a whole. Genetically modified crops have become a common source for genetic pollution, not only of wild varieties but also of domesticated varieties derived from classical hybridization. Genetic erosion coupled with genetic pollution may be destroying unique genotypes, thereby creating a hidden crisis which could result in a severe threat to our food security[21,22].

Global warming is also a major threat to g lobalbiodiversi ty. For example coral reefs - which are biodiversity hotspots- will be lost in 20 to 40 years from now if global warming continues at the current trend[23].

Between 1950 to 2011, world has population increased from 2.5 billion to 7 billion and is forecast to reach more than 9 billion during the 21 st century. The massive growth in the human population had more impact on biodiversity than any other single factor[24,25].

Rates of decline in biodiversity in this sixth mass extinction match or exceed rates of loss in the five previous mass extinction events in the fossil record. This is due to Holocene extinction. Loss of biodiversity results in the loss of natural capital that supplies ecosystem goods and services [26,27].

The forests of Pakistan require special attention for the conservation of environment and sustainable utilization of natural resources. The decrease in forest cover and associated major changes in community composition has led to the decline in population size of many important plants and animals' species[12].

The species that are critically endangered under criteria A are Acer caesium, Betula utilis, Cedrus deodara, Opuntia dilleni, Paeonia emodi, Pistacea integerrima, Skimmia laureola and Taxus wallichiana among plant species while Alectoris chukar, Lophophorus impejanus, Lophura leucomelana and Pucrasia macrolopha among animal species. The species that are critically endangered under criteria B are Opuntia dilleni, Populus alba and Quercus glauca.The species that are critically endangered under criteria C are Quercus glauca and Martes flavigula. The species that are critically endangered under criteria D are Cedrus deodara, Ulmus wallichiana, Viscum album, Panthera pardus, Prionailurus bengalensis, Uncia uncia, Ursus arctos and Ursus Thibetanus.

Hunting, shooting and trapping of wild fauna, extensive grazing, deforestation and loss of habitat are the primary causes of species extinction in the study area[28].

The people of the study area mainly depend on plant and animal species for various purposes, thus leading many species to the verge of extinction[6]. Damage to the plants are careless and illicit cutting and smuggling of trees and shrubs, overgrazing, loss of habitat, converting the plan slopes in the forests for cultivation also exert enormous stress on the vegetation and result in environmental degradation.

The present status of species diversity of the flora and fauna of District Battagram is quite different from what existed only a short time ago. Sadly several valuable species have vanished without a chance of being studied. Therefore plant and animal conservation is a critical task in this particular area.

\section{Conclusions}

A rare species is important at local, national and for the global biodiversity. Wildlife in the study area is a fin ite and precious resource that requires efficient, wise and sustainabl e management and conservation strategies. Hence, immedia te conservation measures are urgently necessary in order to protect the taxon fromextinction.

\section{REFERENCES}

[1] Faizul Haq (2012). The Ethno Botanical Uses of Medicinal Plants of Allai Valley, Western Himalaya Pakistan. International Journal of Plant Research 2012, 2(1): 21-34.

[2] Faizul Haq (2011). Book on Medicinal Plants. Traditional uses of Medicinal Plants of Nandiar Khuwarr Catchment (District Battagram) Pakistan, released by LAP Lambert Academic Publishing - ISBN: 978-3-8443-2976-6.

[3] Sher Muhammad (2003). Resource Management Plan Hillan-Battagram forests.

[4] Sher Muhammad (2004). Resource Management Plan Allai forests.

[5] Anonymous (1998). District Battagram - District Census Report. Ministry of Interior, Islamabad.

[6] Faizul Haq, Habib Ahmad*, Mukhtar Alam, Ishtiaq Ahmad and Rahatullah (2010). Species diversity of vascular plants of Nandiar valley western Himalaya, Pakistan. Pak. J. Bot., Special Issue (S.I. Ali Festschrift) 42: 213-229.

[7] Raup, D. M. (1994). "The role of extinction in evolution". Proceedings of the National Academy of Sciences 91 (15): 6758-6763.

[8] Sahney, S., Benton, M.J. \& Falcon-Lang, H.J. (2010). "Rainforest collapse triggered Pennsylvanian tetrapod diversification in Euramerica" (PDF). Geology 38 (12): 1079-1082.

[9] Sahney, S. and Benton, M.J. (2008). "Recovery from the most profound mass extinction of all time" (PDF). Proceedings of the Royal Society: Biological 275 (1636): 759-65.

[10] Bambach, R.K.; Knoll, A.H.; Wang, S.C. (December 2004). 
"Origination, extinction, and mass depletions of marine diversity". Paleobiology 30 (4): 522-42.

[11] Benton M. J. (2001). "Biodiversity on land and in the sea". Geological Journal 36 (3-4): 211-230.

[12] Jan Alam, S.I. Ali (2009). Conservation Status of Astragalus gilgitensis Ali (Fabaceae): A Critically Endangered Species in the Gilgit District, Pakistan. Phyton. (Horn, Austria) 48(2): 211-225.

[13] Muhammad Ibrar (2003). Conservation of Indigenous Medicinal Plants and their Traditional Knowledge found in Moist Temperate Himalaya Pakistan. Department of Biological Sciences/ Quaid-I-Azam University, Islamabad.

[14] F. Haq (2011). Conservation status of the Critically Endangered and endangered species in the Nandiar Khuwar catchment District Battagram, Pakistan. International Journal of Biodiversity and Conservation Vol. 3(2), pp. 27-35.

[15] "IUCN's Classification of Direct Threats". Conservationmea sures.org.

[16] Paul Ehrlich and Anne Ehrlich, Extinction, Random House, New York (1981) ISBN 0-394-51312-6

[17] C.Michael Hogan. 2010. Deforestation Encyclopedia of Earth. ed. C.Cleveland. NCSE. Washington DC.

[18] Koh L. P., Dunn R. R., Sodhi N. S., Colwell R. K., Proctor H. C., Smith V. S. (2004). "Species Coextinctions and the Biodiversity Crisis" (PDF). Science 305 (5690): 1632-4.

[19] Mooney, H. A.; Cleland, EE (2001). "The evolutionary impact of invasive species". Proceedings of the National Academy of Sciences 98 (10): 5446-5451.

[20] Aubry, C., R. Shoal and V. Erickson. 2005. Grass cultivars: their origins, development, and use on national forests and grasslands in the Pacific Northwest. USDA Forest Service. 44 pages, plus appendices.; Native Seed Network (NSN), Institute for Applied Ecology, $563 \mathrm{SW}$ Jefferson Ave, Corvallis, OR 97333, USA".

[21] Grafton, R. Q.; Kompas, T.; Hilborn, R. W. (2007). "Economics of Overexploitation Revisited". Science 318 (5856): 1601-1601.

[22] Pollan, Michael. "The year in ideas: A TO Z.; Genetic Pollution; By Michael Pollan, The New York Times, December 9, 2001". New York Times.

[23] Coral reefs to be destroyed in 20-40 years". Mnn.com. 200812-10. http://www.mnn.com/earth-matters/wildernessresources/stories/15-of-coral-reefs-already-lost-much-morefeared.

[24] "World Population Growth, 1950-2050". Population Referen ce Bureau.

[25] Population Bomb Author's Fix For Next Extinction: Educate Women". Scientific American. August 12, 2008

[26] Jackson, J. B. C. (2008). "Colloquium Paper: Ecological extinction and evolution in the brave new ocean". Proceedings of the National Academy of Sciences 105: $11458-11465$.

[27] Costanza, R.; d'Arge, R.; de Groot, R.; Farberk, S.; Grasso, M.; Hannon, B.; et al., Karin; Naeem, Shahid et al (1997). "The value of the world's ecosystem services and natural capital". Nature 387 (6630): 253-260.

[28] O.E. Sala, F.S. III Chapin, J.J. Armesto, E. Berlow, J. Bloomfield, R. Dirzo, E. Huber Sanwald, L.F. Huenneke, R.B. Lackson, A. Kinzing, R. Leemand, D.M. Lodge, H.A. Mooney, M. Oesterheld, N.L. Poff, M.T. Sykes, B.H. Walker, M. Walker, D.H. Wall (2000). Global Biodiversity Scen arios for the year 2010. Science, 287: 1770-1774. 